\title{
THE INFLUENCE OF GRAMMAR ON ENGLISH LEARNERS' WRITING ACCURACY AT THE SCHOOL OF MODERN LANGUAGES
}

\author{
La influencia de la gramática en el aprendizaje de la precisión de escritura \\ del inglés en la Escuela de Lenguas Modernas
}

Patricia Córdoba Cubillo*
Mayra Solís Hernández**

\begin{abstract}
This article presents the results of a study conducted in three English courses of the curriculum of the B.A. in English and the B.A. in English Teaching from the School of Modern Languages at the University of Costa Rica. The objective of this investigation was to determine whether the teaching of grammar contents, according to the students' perceptions, helped them to develop their writing accuracy in their first two composition courses. In order to determine if the students' opinions were congruent with their grammar accuracy, some of their writing samples were analyzed. The results show that there was no congruence in some areas.

Key Words: English grammar courses, English writing courses, student grammar mistakes, writing accuracy, grammar

\section{RESUMEN}

Este artículo presenta los resultados de un estudio llevado a cabo en tres cursos de inglés del Plan de Estudios del Bachillerato en Inglés y del Bachillerato en la Enseñanza del Inglés de la Escuela de Lenguas Modernas de la Universidad de Costa Rica. El objetivo de esta investigación era determinar si, según las percepciones de los estudiantes, la enseñanza de contenidos gramaticales les ayudó a desarrollar las destrezas de escritura en los dos primeros cursos de composición. Para determinar si hubo congruencia entre las percepciones de los estudiantes y su precisión gramatical, se analizaron muestras de sus composiciones. Se determinó que hubo incongruencias en algunos aspectos.

Palabras clave: Cursos de gramática inglesa, cursos de composición inglesa, errores gramaticales, escritura precisa, gramática
\end{abstract}

\footnotetext{
* Universidad de Costa Rica. Docente, Escuela de Lenguas Modernas. Costa Rica. Correo electrónico: pcordobac@gmail.com

** Universidad de Costa Rica. Docente, Escuela de Lenguas Modernas. Costa Rica.

Correo electrónico: mayras04@gmail.com

Recepción: 3/12/2014. Aceptación: 30/4/2015.
} 


\section{Introduction}

Grammar is an essential component in any language learning process. In some curricula, grammar and writing are taught as two separate courses, being this the situation of the B.A. in English and the B.A. in English Teaching at the School of Modern Languages in the University of Costa Rica. These B.A. curricula share a common linguistic component which includes areas such as speaking, reading, writing, and grammar. Four courses aim at developing grammar content and six other courses at developing the students' writing skills. The present project involved only the first grammar course and the first two writing courses in the curricula. The purpose of this study is to determine whether the content studied in the first grammar course helped students improve their writing accuracy in Composition I and Composition II. The results of this study show that the students believed that the grammar topics did help them to write more accurately; however, the analysis of student writing samples collected at the end of the term in those two composition courses indicates that the students still make a great number of grammar errors in their writing.

\section{Review of Literature}

This section provides various grammar definitions and explores the following linguistic areas which are intrinsically related to the language learning process: interlanguage, types of errors, approaches to teaching grammar, and the influence of grammar on English learners' writing accuracy.

\subsection{Definition of grammar}

Grammar has been vastly defined by different authors. Ur (as cited in Nunan, 2005) considers that grammar may be roughly described as the way language manipulates and combines words (or bits of words) in order to form longer units of meaning. Another definition of grammar by Richards, Platt and Weber (as cited in Nunan, 2005) states that grammar is a description of the structure of a language and the way in which units such as words and phrases are combined to produce sentences in the language. Harmer (as cited in Nunan, 2005) defines the way in which words change themselves and group together to make sentences. The grammar of a language is what happens to words when they become plural or negative, or what order is used when we make questions or join two clauses to make one sentence. Weaver (as cited in Freeman and Freeman, 2004) defines grammar based on its meanings: (1) grammar as a description of syntactic structure; (2) grammar as prescriptions for how to use structures and words; (3) grammar as rhetorically effective use of syntactic structures; (4) grammar as the functional command of sentence structure that enables us to comprehend and produce language. It is important to mention here that Weaver's second meaning of grammar is the one that prevails in the Grammar I course at the School of Modern Languages.

The term interlanguage was introduced by Selinker in the early 70 s. It refers to the intermediate states of a learner's language in the L2 learning process. Interlanguages, also called interim grammars (Saville-Troike, 2006) have been defined by Nunan (1999) as the languages produced by learners in the course of acquiring the target language. He believes that during the language learning process, learners go through a series of interlanguages. Although these interlanguages deviate from the target language, they have sets of rules that are internally consistent. Cook (2001) also refers to interlanguage, but she prefers to call it learner's independent language, that is, the learner's own temporary language system. Learners' sentences, though peculiar and limited, show rules and patterns that indicate some consistency, and in each stage of the language learning process, learners have their own languages systems or interlanguages which are systematic. Since learner's interlanguages reflect their temporary language systems, their 
deviations from the target language should be considered as an inevitable and natural part of the learning process (Cook, 1999). Additionally, Muñoz Luna (2010) states that

the different instances of Interlanguage should be perceived as a proof of the learner's assimilation of the new language into his/her own reality; they are also a sign that the learning activity is meaningful for learners. However, Interlanguage is not only a measurable evidence of language learning, rather it is the complex result of internal cognitive processes that take place during learners' process of second language (SL) acquisition. (p. 61)

Interlanguage can be compared to children's first language development. Children gradually develop their native language in systematic stages; likewise, adults show a systematic progression of acquisition of phonological and grammatical features, and successful interlanguage development is the result of utilizing feedback from others (Brown, 2001). Fossilization is another fundamental characteristic of any interlanguage (Tarone, 2006). Fossilized interlanguages stop their development at some point in the learning process of the target language.

\subsection{Types of errors}

Corder (as cited in Ellis and Barkhuizen, 2005) distinguishes errors from mistakes. Errors arise because of gaps in the learner's knowledge; mistakes occur because of the difficulty of processing forms that are not yet fully mastered. Ellis and Barkhuizen suggest that instructors analyze samples of learner language as a test to determine if the learner is making an error or a mistake. If the learner alternates between the erroneous form and the correct target-language form, then that can be identified as a mistake. These authors also indicate that the best way to determine if a deviant form is a mistake is to consult the learner. If the learner can selfcorrect the erroneous form, it can be classified as a mistake.

In addition, in the case of written language, Thornbury (1999) classifies errors into three categories: lexical errors, grammar errors and discourse errors. Lexical errors include mistakes in the way words are combined. Grammar errors deal with mistakes in subject-verb agreement, verb tenses, verb forms, adverb misplacement, order of adjectives, use of articles, plural formation, among others. Discourse errors relate to the way sentences are organized and linked in order to make whole texts. Although lexical errors are corrected in all the courses considered in this study, for the purposes of this article, only grammar errors will be analyzed. The reason for this decision is that the syntactic analysis done in the Grammar I course does not go beyond the sentence level. Learner errors have been categorized into 18 groups (Hasbún, 2009). From these categories, five are also examined in this study (articles, number/agreement, adjectives, pronouns, and possessives). In another study on student writing performance also by Hasbún (2007), she found differences between teachers' perceptions and students' opinions about student performance. While students reported that they were able to use what they had learned in the grammar course, their teachers reported that those students were still making serious mistakes on subject verb agreement, count nouns, and sentence pattern production. These three types of errors are also examined in this study.

\subsection{Approaches to teaching grammar}

Two of the most frequently used methodologies to teach grammar are the deductive and inductive approaches (Nunan, 2005). In a deductive approach, the teacher presents the grammar rule and then gives students exercises in which the learners apply the rule. This is the type of approach mainly used in the Grammar I course at the School of Modern Languages. This approach presents the following advantages: (a) it saves time because it gets straight to the point. Many rules can be more quickly explained than elicited, thereby allowing more time for practice and application. (b) It allows for teachers to deal with language points as they come up, and (c) it confirms many students' expectations about classroom learning, particularly for those with analytic learning 
styles. However, one disadvantage of this approach is that grammar explanations may be frustrating, especially for students who do not have enough language to talk about language, that is, metalanguage. Another drawback is that grammar explanations are seldom as memorable as other forms of presentation such as demonstration, and they encourage teacher-centered classes. Moreover, such an approach promotes the belief that learning a language is simply a case of knowing the rules (Nunan, 2005).

In an inductive approach, the teacher presents samples of language, and the students have to come to an intuitive understanding of the rule. One advantage of this approach is that when learners themselves discover the rules, these rules become more meaningful and memorable. Another benefit is that classes become more student-centered, and students are more motivated, attentive, self-reliant, and autonomous. Nevertheless, one weakness of this methodology is that students may spend a great deal of time working out the rule. Another negative aspect is that students may come up with the wrong rule, or their version of the rule may be too broad or too narrow because some rules are very difficult to state. The last limitation is that some students may be frustrated because they prefer the instructors to explain the rules to them (Nunan, 2005).

\subsection{The influence of grammar on English learners' writing accuracy}

Much research on the formal teaching of grammar has been carried out. Researchers have wondered if there is a direct influence of grammar on learner writing performance. Findings indicate that there is no such influence. Evidence of this is provided by Freeman and Freeman (2004) who state that students have trouble learning traditional grammar and applying grammar rules when they write or speak. Weaver (as cited in Freeman and Freeman, 2004) has also reviewed much of the research on teaching grammar and has come to the same conclusion. Krashen (as cited in
Freeman and Freeman, 2004), who has done investigation on the traditional prescriptive teaching of grammar, concludes that there is no relationship between grammar study and writing; that is, there is no relationship between formal grammar instruction and performance on measures of writing ability. In the same line of thought, Braddock, Lloyd-Jones, et al (as cited in Freeman and Freeman, 2004) state:

In view of the widespread agreement of research
studies based upon many types of students and
teachers, the conclusion can be stated in strong
and unqualified terms: the teaching of formal
grammar has a negligible or, because it usually
displaces some instruction and practice in
actual composition, even a harmful effect on the
improvement of writing. (p. 218)

Regarding effective grammar teaching, research strongly suggests that the most beneficial way of helping students improve their command of grammar in writing is to use students' writing as the basis for discussing grammatical concepts (Chin, 2000). Researchers agree that it is more effective to teach punctuation, sentence variety, and usage in the context of writing than to approach the topic by teaching isolated skills (Calkins, 1980; DiStefano and Killion, 1984). Chin (2000) also believes that

\footnotetext{
as students revise and edit their writing, teachers can provide grammar instruction that guides students in their attempts to identify and correct problems in sentence structure and usage. For example, a teacher who sees that many students are writing sentences containing misplaced modifiers can present a mini-lesson on this concept, using examples from student writing. The teacher can have students edit their own and one another's drafts for this problem. Integrating grammar instruction into the revising and editing process helps students make immediate applications, thus allowing them to see the relevance of grammar to their own writing (p.1).
}

Taking into account what literature has stated about the teaching of grammar and its effect on writing, the following research question has guided this study: How do Grammar I contents help English learners develop their writing accuracy? 


\section{Method}

\subsection{Setting}

This research study took place in one grammar course and two writing courses of the BA in English and the BA in English Teaching. English Grammar I is the first of four grammar courses in the curricula. It aims at introducing the students to the formal study of English grammar. It helps the students to develop their ability to use grammar structures accurately, meaningfully, and appropriately in the target language. English Composition I is the first of six required composition courses in the curricula. It provides the students with the essential elements needed to write a formal academic paragraph based on the principles of the process and genre approaches. English Composition II is the second required composition course in the curricula. This course intends to help the students develop effective writing skills applying the principles of essay writing.

\subsection{Participants}

This study involved 196 students from the B.A in English and the B.A. in English Teaching; 88 were taking English Grammar I; 65 were enrolled in English Composition I and 43 in English Composition II. Their ages range from 18 to 48 . These three courses belong to the second-year curriculum of the two B.A. programs.

\subsection{Instruments}

Two instruments were used to collect data: a form indicating the courses the students were taking at that time (Appendix 1), and a questionnaire which included two sections (Appendix 2). In the first part, the participants were asked to rate the degree of usefulness of Grammar I topics. In the second section, the students were asked to answer four questions regarding the usefulness of the same topics.
They were also requested to express the reasons why those topics helped or did not help them in their writing courses.

\subsection{Procedures}

a. Students from all groups of Grammar I, Composition I and II completed a form indicating the courses they were taking at that time.

b. Students from all groups of Grammar I, Composition I and II completed the questionnaire.

c. Data from the questionnaires were tallied.

d. Writing samples from Composition I and Composition II students were collected. Those compositions were the last piece of writing produced by the students in each course.

e. Students' grammar mistakes were identified in all students' compositions.

f. Grammar mistakes were classified into different categories and subcategories, corresponding to the topics studied in Grammar.

\section{Results and Discussion}

Two sets of results are presented in this section. The first set shows the participants' opinions about the usefulness of the topics studied in Grammar I. The second set displays the students' most common mistakes found in their writing samples.

\subsection{Participants' opinions about topics studied in Grammar I}

Table 1 shows Grammar I students' opinions about the usefulness of the topics studied in the course. 
TABLE 1

Percentages of Grammar I students' responses about topic usefulness in the course

\begin{tabular}{llllllll}
\hline \multirow{2}{*}{ Topics } & \multicolumn{3}{l}{ Degree of usefulness } & \multicolumn{3}{l}{ Percentages } \\
\cline { 2 - 8 } & $\mathbf{4}$ & $\mathbf{3}$ & $\mathbf{2}$ & $\mathbf{1}$ & Helpful & Not helpful & NR \\
\hline Subject-verb agreement & 60 & 31 & 8 & 1 & 91 & 9 \\
\hline Quantifiers & 33 & 49 & 16 & 2 & 82 & 18 \\
\hline $\begin{array}{l}\text { Types of adverbials (frequency, manner, place, } \\
\text { time, reason/purpose) }\end{array}$ & 43 & 37 & 15 & 5 & 80 & 20 \\
\hline Use of articles & 39 & 40 & 18 & 3 & 79 & 21 \\
\hline Types of nouns (mass, count, collective) & 40 & 36 & 16 & 8 & 76 & 24 \\
\hline Possessives & 37 & 40 & 22 & 1 & 77 & 23 \\
\hline Noun modifiers & 43 & 34 & 18 & 5 & 77 & 23 \\
\hline Sentence patterns & 36 & 34 & 17 & 12 & 70 & 29 \\
\hline $\begin{array}{l}\text { Types of pronouns (personal, reflexive, reciprocal, } \\
\text { indefinite, demonstrative, interrogative, relative) }\end{array}$ & 27 & 43 & 24 & 5 & 70 & 29 \\
\hline
\end{tabular}

4: A very great deal 3: A lot 2: A little 1: Very little; Helpful $=4+3$; Not helpful $=2+1$; NR $=$ No response, $n=88$ Source: Questionnaire filled out by Grammar I students

As indicated in Table 1, for Grammar I students, the three most helpful topics in their writing classes were subject-verb agreement (91\%), quantifiers (82\%) and adverbials $(80 \%)$. The least helpful topics were pronouns $(70 \%)$ and sentence patterns $(70 \%)$.
The students enrolled in Composition I also stated their opinions about the usefulness of the topics studied in Grammar I. Table 2 shows these results.

TABLE 2

Percentages of Composition I students' responses about Grammar I topic usefulness

\begin{tabular}{llllllll}
\hline \multirow{2}{*}{ Topics } & \multicolumn{3}{c}{ Degree of usefulness } & \multicolumn{3}{l}{ Percentages } \\
\cline { 2 - 8 } & $\mathbf{4}$ & $\mathbf{3}$ & $\mathbf{2}$ & $\mathbf{1}$ & Helpful & Not helpful & NR \\
\hline Subject-verb agreement & 77 & 15 & 6 & 2 & 92 & 8 & 12 \\
\hline Quantifiers & 45 & 43 & 8 & 4 & 88 & 12 & 2 \\
\hline Types of nouns (mass, count, collective) & 51 & 35 & 9 & 3 & 86 & 15 & 2 \\
\hline Noun modifiers & 54 & 29 & 9 & 6 & 83 & 19 & 18 \\
\hline Use of articles & 58 & 23 & 14 & 5 & 81 & & 2 \\
\hline Possessives & 46 & 35 & 15 & 3 & 81 & & 1 \\
\hline $\begin{array}{l}\text { Types of adverbials (frequency, manner, place, } \\
\text { time, reason/purpose) }\end{array}$ & 43 & 38 & 12 & 6 & 81 & 18 & \\
\hline $\begin{array}{l}\text { Types of pronouns (personal, reflexive, reciprocal, } \\
\text { indefinite, demonstrative, interrogative, relative) }\end{array}$ & 43 & 32 & 17 & 8 & 75 & 25 & \\
\hline Sentence patterns & 40 & 26 & 21 & 12 & 66 & 33 & 1 \\
\hline
\end{tabular}

4: A very great deal 3: A lot 2: A little 1: Very little; Helpful $=4+3$; Not helpful $=2+1$; NR $=$ No response, $n=65$ Source: Questionnaire filled out by Composition I students 
As seen in Table 2, for Composition I students, the three most helpful topics in their writing classes were subject-verb agreement (92\%), quantifiers (88\%) and types of nouns (86\%). The least helpful topic was sentence patterns $(66 \%)$.
The students enrolled in Composition II gave their opinions about the usefulness of the topics studied in Grammar I as well. Table 3 shows these results.

TABLE 3

Percentages of Composition II students' responses about Grammar I topic usefulness

\begin{tabular}{|c|c|c|c|c|c|c|c|}
\hline \multirow[t]{2}{*}{ Topics } & \multicolumn{3}{|c|}{ Degree of usefulness } & \multicolumn{3}{|c|}{ Percentages } & \multirow[b]{2}{*}{ NR } \\
\hline & 4 & 3 & 2 & 1 & Helpful & Not helpful & \\
\hline Subject-verb agreement & 61 & 28 & 3 & 5 & 89 & 8 & 3 \\
\hline Types of nouns (mass, count, collective) & 44 & 42 & 7 & 7 & 86 & 14 & \\
\hline Possessives & 47 & 35 & 14 & 3 & 82 & 17 & 1 \\
\hline Noun modifiers & 44 & 37 & 16 & 0 & 81 & 16 & 3 \\
\hline Sentence patterns & 30 & 51 & 10 & 7 & 81 & 17 & 2 \\
\hline $\begin{array}{l}\text { Types of pronouns (personal, reflexive, reciprocal, } \\
\text { indefinite, demonstrative, interrogative, relative) }\end{array}$ & 44 & 35 & 17 & 0 & 79 & 17 & 4 \\
\hline Use of articles & 49 & 28 & 17 & 3 & 77 & 20 & 3 \\
\hline Quantifiers & 40 & 37 & 17 & 0 & 77 & 17 & 6 \\
\hline $\begin{array}{l}\text { Types of adverbials (frequency, manner, place, } \\
\text { time, reason/purpose) }\end{array}$ & 37 & 35 & 21 & 0 & 72 & 21 & 7 \\
\hline
\end{tabular}

4: A very great deal 3: A lot 2: A little 1: Very little; Helpful $=4+3$; Not helpful $=2+1$; NR $=$ No response, $n=43$ Source: Questionnaire filled out by English Composition II students

As shown in Table 3, for Composition II students, the three most helpful topics in their writing classes were subject-verb agreement $(89 \%)$, types of nouns $(86 \%)$ and possessives $(82 \%)$. The least helpful topic was types of adverbials (72\%).

As shown in Tables 1,2 and 3, the students from the three different courses reported that the most helpful topic in their writing classes was Subject-verb agreement (91\%, 92\% and $89 \%$ respectively). Quantifiers was the second most useful topic according to Grammar I and Composition I students. Evidence of this finding is clearly seen in the fact that only a few errors in quantifiers were present in the students' writing samples. However, Composition II students indicated that Types of nouns was the second most useful topic (86\%). The third most helpful topic for Grammar I students was Types of adverbials (80\%), for Composition I students was Types of nouns (mass, count and collective) (86\%), and for Composition II students was Possessives (82\%). A plausible explanation why the participants in the three groups thought that subject-verb agreement was the topic that helped them the most in their writing may be the high frequency of subject-verb agreement use. Since most of the times the subject in an English sentence is a required element, the students could not avoid using subject-verb agreement in their writing. In other words, in almost any sentence they wrote, the subject + verb 
+complement pattern was used. Consequently, by looking at the high percentages reported by these participants, we may tend to believe that they would make no mistakes in subject-verb agreement. However, the results of this study proved this wrong because a great number of mistakes in this area were found.

\subsection{Common errors found in students' writing samples}

The following section examines some of the errors in the areas of subject-verb agreement, quantifiers, nouns, types of adverbials, adjectives, article usage and sentence patterns.

\subsubsection{Subject-verb agreement mistakes}

The errors in subject-verb agreement found in the students' writing samples listed here are classified into five groups. Each mistake in the verb form has been underlined. This first group shows errors dealing with nouns:

a. $\quad .$. in case the husband get all the money ...

b. This parent have to work ...

c. Technology are making people do more activities at the same time...

d. A single-parent family consist of one parent and his or her children...

e. The news most of the time say ...

f. Technology give people several advantages.

g. People is becoming sedentary.

h. That name were given because many of them are children of baby boomers

i. People think that black people is lazy.

j. Diabetes have been increasing dramatically.

k. Today's woman are more concerned about their rights.

1. If the student have a question about some topic...

m. DSD guidelines advises that ...
Most of the errors in this group indicate that the learners had not mastered those subjectverb agreement rules for nouns which are always singular or plural like news, diabetes and people. In other cases, the learners were not able to identify the headnoun in the subject of the sentence as singular or plural, for example, a single-parent family consist ... We may also speculate that the learner thought that adding an -s to the verb indicated plural form.

The errors shown in this second group deal with compound subjects:

a. Climate change is the alteration of the climate which one country or place have had during a long period of time.

b. A man and a woman has been a couple for five years...

c. All this hate and tolerance is not positive in any way.

d. The positive or negative impact that it may produce depend on the way...

We believe that the learners did not know that the coordinating conjunction and, when used to join two singular nouns, makes the phrase plural. When the coordinating conjunction or was used, the verb agrees with the last part of the phrase. Apparently, the learners paid attention to the singular form of the noun closer to the verb, and mistakenly used the singular form of the verb.

The following errors were found in relative clauses:

a. $\quad .$. in the body of a person who suffer from this disease. (relative clause)

b. One of the main factors that contributes to the formation...(relative clause)

c. Many believe that using different clothes make them ... (gerund as subject of a clause).

d. Another advantage of the development of modern drugs is that it have less side effects (pronoun, subject of a clause). 
e. People who cares about others and tries every day to achieve peace ... (count plural noun as

subject followed by a relative clause)

f. Costa Ricans who depends on tourism. (relative pronoun as subject of a clause)

g. Children are surrounded by fast-food restaurants that shows fake happiness... (count noun followed by a relative clause)

Examining the mistakes in this third group, we could think that, in one case, the learner might have thought that the word one was the subject of the verb of the that-clause. $\mathrm{He}$ missed the fact that the verb contributes refers to factors, so the correct form should be contribute. In another case, the verb suffer should be singular. Another type of error is shown in the following example: Many believe that using different clothes make them... In this case, the student erroneously thought that the verb had to agree with the word clothes. He did not recognize that the gerund using was the subject in this sentence.

The two mistakes found in headwords modified by a prepositional phrase are these:

a. This type of moles are the first stage

b. This type of family adopt a child or more.

These two mistakes probably occurred because the student might have thought that the noun family was a collective noun; therefore, this noun had to agree with the verb adopt. In the other case, the noun moles was thought to agree with the form of the verb be.

Errors in pronouns as subject of the sentence were also found:

a. Both differs in some aspects.

b. It help them to have a better life.

c. This affect directly the child's will.

d. This make a difference.

e. Almost everyone have a place to sit down.

All the errors in the previous group, except the first one, indicate that the student did not realize that the pronoun was singular. On the contrary, the pronoun both is plural and the verb was written in the singular form.

\subsubsection{Errors dealing with quantifiers}

a. Diabetes and blood hypertension develop less complications...

b. It has less cafeterias

c. less years

d. they are home to much less people

e. there are much many companies

f. people should follow each steps

g. much species of animals and trees

h. A large number of people does outdoor activities

In the above group, some quantifiers are singular, and some others are plural. These errors show that the student had not mastered the rules regarding the correct use of quantifiers.

\subsubsection{Errors dealing with nouns}

The following are errors found in the use of possessive nouns:

a. On the contrary, today technology...

b. This argument is in the magazine of Dr. Byron.

c. In contrast to today children ...

d. many of them are children of baby boomers

e. the eco boomers are the sons and daughters of the baby boomers

f. many of them spend the money of their parents ...

g. in the lives of people...

h. ... the bodies of these people ...

The errors in this group have to do with the wrong use of the preposition of to indicate possession when the noun refers to people and time. Obviously, the student did not remember the rules of apostrophe s ('s). 
The following group of errors is related to the missing plural form of nouns:
a. on people's mind
b. types of family
c. all kind of violent actions
d. Those cellphones have more functions than sending message or making call.
e. These advance
f. the majority of television program
g. some of these program
h. women could enjoy their lives in all the aspect that means to be a woman...

The first three mistakes may be the result of Spanish interference. According to Cook (2001: 14), "the view of L2 learning sees its crucial element as the transfer of aspects of the first language to the second language. The first language helps learners when it has elements in common with the second language and hinders them when they differ." In Spanish, for instance, it is acceptable to say en la mente de la gente, tipos de familia and toda clase de actos violentos using the singular form of the nouns mind, family and kind, but in English this structure is not allowed. The other errors might have been just careless writing.

Only two errors using a noun instead of an adjective were found in the samples:
a. to have a health skin...
b. people need to have a strength skin

These errors show the wrong use of a part of speech. The student wrote the noun instead of the corresponding adjective (healthy, strong).

\subsubsection{Errors dealing with types of adverbials}

In this section, errors dealing with adverbial misplacement are shown:

a. The behavior in children most of the time is quiet

b. children have fewer worries than adolescents because they depend most of the time on their parents' decisions c. ... married people have very often fights and different opinions about ...

d. We can see very clearly that the concept of the term family it is very different nowadays from the past

e. The technological world in which we are living has changed drastically people's life styles.

f. He had the honor to win many years ago the Nobel Peace Prize.

g. In contrast, men are most of the time very "mathematic" and productive ...

h. People who try every day to achieve peace ...

i. It also has ended with some diseases around the world such as the smallpox.

j. ...it probably will be hard for you to focus in just that one activity

k. Skin cancer damages permanently the body.

1. A person with asthma many times has difficulty to breathe.

m. It can spread the cancer cells easily to other organs.

n. if she does not follow correctly the instructor's indications...

o. Important people lived there like Bach and Goethe.

p. A student cannot understand well grammar if she does not do enough practice.

q. They can help foreigners understand better another language.

By looking at the large number of errors in wrong adverb position, we could say that we find a mismatch between what was reported by the students as a helpful topic and their writing accuracy. Although adverbs are very movable elements in a sentence, errors in adverb misplacement were abundant in the student's writing samples.

Using an adverb instead of an adjective was another mistake present in the students' writing samples: 
a. Furthermore, they are put under politically, economically, and socially pressure to do what the developed countries want

b. ...while, alternative medicine is a slowly way of treating diseases...

c. ...a more seriously sickness...

d. ...exposure to artificially UV rays

e. It is mainly produced by directly sun exposure.

Even though the mistaken words in this section end in -ly, which frequently indicates adverbs of manners, the student was not aware of this fact and used them incorrectly as if they were adjectives.

In addition, two mistakes related to subject omission after an adverbial phrase were found in the learners' writing texts:

a. In order to be in peace with yourself is necessary to live peacefully with nature and people.

b. While multi-tasking is easier to make mistakes...

A possible explanation for these two errors might be that the student thought that the adverbial phrase was the subject of the sentence.

\subsubsection{Errors dealing with adjectives in plural form}

a. Because of the differents rights...

b. Many Neo-Nazis colonies have settled there.

Spanish interference might have been the cause for these two mistakes, which involved using the plural form of adjectives. In Spanish, agreement of adjectives and nouns is mandatory, but this does not happen in English.

\subsubsection{Errors dealing with articles}

The large number of errors dealing with articles corresponds with the low degree of usefulness reported by the students. As seen in
Tables 1, 2 and 3 the participants did not report a high degree of usefulness of the topic of articles.

The students omitted using an article in many instances. These mistakes are presented here:

a. Family is a group of people who are...

b. Family is a type of organization...

c. In addition, nuclear family ...

d. The absence of army is one of the most peaceful characteristics of Costa Rica.

e. If a girl was not virgin ...

f. Single-mother family is characterized by

g. Hypnosis and acupuncture could be used in patients that have restriction with anesthesia

h. when physician only recommended blood tests and X-rays...

i. $\quad$ Staying single is not cause for mockery.

j. The second main difference is the kind of abilities student needs ...

k. Internet is a technological tool that allows ...

1. She must use sunscreen lotion all of the time in order to protect skin.

m. Now, modern scientists have studied and proved their positive... human body.

n. ...they kicked us out of classroom...

o. In other words, adolescence stage faces many important changes.

p. ...when He-man program started...

q. It was the most important goal in girl's life...

r. Meditation and yoga are two disciplines that have to do with posture and relaxation of the ...

In the examples shown above, the students did not include either the indefinite article a/an or the definite article the before the noun.

Not only did the students make a lot of mistakes in article omission, but also they 
overused the rules of correct article usage. The mistakes in this aspect are presented here:

a. $\quad . .$. and the foster parents raised the child as their biological son or daughter ...

b. Not only is the water a problem but also the food because of ...

c. The food is more expensive...

d. The divorce is a social problem that ...

e. The divorce is a rupture of ...

f. ... the economy is involved too because the people have to pay...

g. The last reason that leads a marriage to get divorced is the financial problems.

h. The peace among countries is as unstable as peace at home in America.

i. The peace is an important factor that plays a significant role in the progress of a country.

j. The peace is a value that represents a rejection ...

k. The history is always told by the perspective of the winner.

1. The humankind has to remember that peace is necessary in our lives ...

m. Multi-tasking offers benefits not only for employers but also for the employees

n. with rules about the school, work...

o. "Children and Television Today" by the Dr. Tanya Byron

p. a different point of view of the life

q. in the recent years

All the examples in this area illustrate overgeneralization of the use of the definite article the; that is, the students inserted the definite article where it was not needed. We may speculate that Spanish interference again made the students include the article.

\subsubsection{Errors dealing with sentence patterns}

Seven errors in sentence patterns were found in the students' compositions: a. MRI has made possible diagnosis of many diseases ...

b. These facts make possible a high selfesteem for people who feel peace.

c. research has made possible the implementation of alternative treatments

d. ...for avoiding skin cancer and keeping healthy the body...

e. we can explain them that violence cannot be a good answer for differences

f. Private clinics and doctors prescribe their patients different medicines.

g. The public sector offers to patients the most urgent, necessary interventions.

Examples a, b, c and d indicate that the students had not mastered pattern 7: N V N Adj. The adjectival was placed before the second nominal as it is usually done in English. Examples e to $\mathrm{g}$ do not follow pattern $5: \mathrm{N} \mathrm{V} \mathrm{N}$ to/for $\mathrm{N}$. The verb explain requires the preposition to after the second nominal, and the verb prescribe needs the preposition for after the direct object. In example g, the indirect object (patients) appears before the direct object (interventions) and must not have the preposition to.

The participants were asked about the reasons why certain grammar topics had or had not helped them in their writing classes, but some of their answers did not address the question asked. Some others were very vague or nonexistent. A possible explanation may be that the students lack metalinguistic awareness to describe language problems and types of errors in their writing, so they could not provide appropriate answers. Another reason for the students' vague answers might be they were not aware they were not making any mistakes in their writing texts. The students were also asked about the topics to include in or eliminate from the Grammar I course; however, they were unable to give any relevant information.

According to Hasbún (2009: 456), "knowledge gained in (formal lessons in) the classroom remains inactive or inert when put into service (in communication within and) outside the classroom. Students can recall the grammar 
rules when they are asked to do so but will not use them spontaneously in communication, even when they are relevant." In like manner and based on our experience, we believe that students feel frustrated when they are exposed to spontaneous conversations, and they fail to apply the grammar rules correctly. Similarly, they have the same feeling in their writing tasks. To exemplify this frustration, we can use the topic of pattern identification. In our grammar classes, the students are asked to identify grammar patterns, and they are usually successful; however, the identification of patterns does not guarantee that learners apply those patterns well when writing their compositions.

\section{Conclusions}

a. Students keep on making mistakes after having finished Grammar I. In other words, the grammar structures were not acquired. Apparently, there is not enough class time to practice the grammar structures for the students to internalize such structures and use them correctly in their compositions. Although students pass the grammar course satisfactorily, they still make a great number of errors in the compositions they write.

b. Students consider the Grammar I topics very useful; however, they keep writing faulty sentences. For example, there are students who after having passed the grammar course with high grades fail composition courses.

c. Grammar I students are able to identify the structures studied in class, but they cannot produce them well in their compositions.

d. In the Grammar I course, grammar is taught traditionally; in other words, teachers continue to teach traditional prescriptive grammar.

\section{Recommendations}

a. Teachers should teach grammar and composition as only one integrated course. The same teacher should be responsible for organizing both areas: grammar and composition so that the mistakes found in students' writing can be used to teach grammar in context.

b. Teachers should avoid teaching prescriptive grammar. To support this statement, we would like to cite Cook (2001) who states that language should be taught as it is, not as it ought to be. She believes that prescriptive grammar is all but irrelevant to the language teaching classroom. Students should learn to use the target language the way most native speakers do, not an artificial form that nobody uses.

c. Teachers should use inductive grammar teaching as much as possible. By doing this, teachers help learners become more autonomous since they are required to do some noticing and to generate the rules of the structures.

d. Teachers should present mini-lessons using examples from student writing. The teacher can have students edit their own and one another's drafts for this problem. Integrating grammar instruction into the revising and editing process helps students make immediate applications, thus allowing them to see the relevance of grammar to their own writing. (Chin, 2000).

e. Teachers should have their students rewrite every composition once or twice if necessary.

f. Teachers should integrate grammar instruction into the revising and editing process. This helps students make immediate applications and allows them to see the significance of grammar in their own writing. 


\section{Bibliography}

Brown, H. Douglas. 2001. Teaching by principles: An Interactive Approach to Language Pedagogy. New York: Longman.

Calkins, Lucy McCormick. 1980. When Children Want to Punctuate. Language Arts, LVII, 567-573.

Chin, Beverly Ann. 2000. The Role of Grammar in Improving Student's Writing. Retrieved from http://www.uwplatt.edu/ ciesield/ graminwriting.htm

Cook, Vivian. 2001. Second Language Learning and LanguageTeaching. London: Arnold.

DiStefano, Philip \& Joellen Killion. 1984. Assessing Writing Skills Through a Process Approach. English Education, XVI (4), 203-207.

Ellis, Rod and Gary Patrick Barkhuizen. 2005. Analysing Learner Language. Oxford: Oxford University Press.

Freeman, David E. and Yvonne Freeman. 2004. Essential Linguistics: What You Need to Know to Teach. Portsmouth: Heinemann.

Hasbún Hasbún, Leyla. 2007. "Evaluación de un curso de Gramática del Inglés: Insumo para la investigación". Revista Electrónica Actualidades Investigativas en Educación, VII (1): 1-20.

2009. "Teacher and Learner Perceptions of Language-Learning Problem Areas." Revista de Lenguas Modernas, X: 443462.

Muñoz Luna, Rosa. 2010. "Interlanguage in undergraduates' academic English:
Preliminary results from written script analysis.” Encuentro, XIX: 60-73.

Nunan, David. 1999. Second Language Teaching \& Learning: Boston: Heinle \& Heinle Publishers.

2005. Practical English Language Teaching: Grammar. New York: McGrawHill.

Saville-Troike, Muriel. 2006. Introducing Second Language Acquisition. Cambridge: Cambridge University Press: Cambridge

Tarone, Elaine. 2006. Interlanguage. Retrieved from http://socling.genlingnw.ru/files/ya/ interlanguage Tarone. PDF.

Thornbury, Scott. 1999. How to Teach Grammar. Harlow: Longman.

\section{Appendices}

\section{Appendix 1}

UNIVERSIDAD DE COSTA RICA ESCUELA DE LENGUAS MODERNAS

Estimado(a) estudiante, sírvase completar la siguiente información.

Nombre

Marque con X.

Femenino Masculino

Marque con X los cursos que lleva.

Gramática Inglesa I

Composición I

Composición II 
Appendix 2

UNIVERSIDAD DE COSTA RICA ESCUELA DE LENGUAS MODERNAS

We would like to ask you to help us by answering the following questions concerning grammar and writing courses at LM. We would like to know the degree in which the grammar contents studied in LM-1234 have helped you develop your writing skills.

Age _____ Mark with an X: Male Female Composition I Composition II

I. Based on the following rating scale, check $(\sqrt{ })$ the criterion that best describes how useful these topics have been in your writing classes.

4: A very great deal 3: A lot 2: A little 1: very little

$\begin{array}{llll}4 & 3 & 2 & 1\end{array}$

Topics

Types of nouns (mass, count, collective)

Subject-verb agreement

Types of pronouns (personal, reflexive, reciprocal, indefinite, demonstrative, interrogative, relative)
The use of articles

Quantifiers

Possessives

Noun modifiers

Types of adverbials (frequency, manner, place, time, reason/purpose)

Sentence patterns

II. Answer the following questions. Elaborate your answers as much as possible.

1. Which topics from the ones above have helped you improve your writing skills? Why?

2. Which topics from the ones above have not helped you in your composition courses? Why?

3. What other grammar topics should be included in the Grammar I course? Why?

4. What grammar topics should be eliminated from the Grammar I course? Why?

Thank you for your help!

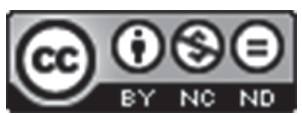

Este obra está bajo una licencia de Creative Commons

Reconocimiento-NoComercial-SinObraDerivada 4.0 Internacional. 
